\title{
Anti-Inflammatory Effect of Centella asiatica (L.) Extract by Decreasing TNF- $\alpha$ Serum Levels in Rat Model of Traumatic Brain Injury
}

\author{
Nafiisah, ${ }^{1}$ Falah Faniyah, ${ }^{2}$ Yoga Mulia Pratama $^{3}$ \\ ${ }^{1}$ Histology Department, Faculty of Medicine Jenderal Soedirman University, Purwokerto, Central Java, Indonesia \\ ${ }^{2}$ Department of Pediatrics/Faculty of Medicine Jenderal Soedirman University, Purwokerto, Central Java, \\ Indonesia, ${ }^{3}$ Department of Internal Medicine/Faculty of Medicine Jenderal Soedirman University, Purwokerto, \\ Central Java, Indonesia
}

\begin{abstract}
Centella asiatica (L.) has many active ingredients with many important roles, including as antioxidant, antiinflamation and neuroprotectant. Centella asiatica (L.) can reduce inflammatory reactions by inhibiting the activity of TNF- $\alpha$. Thus, Centella asiatica (L.) is a potential alternative therapy for traumatic brain injury by reducing inflammation via TNF- $\alpha$ expression modulation. This study aimed to determine the effect of Centella asiatica (L.) on serum TNF- $\alpha$ levels in rat model of traumatic brain injury. This study was conducted during the period of July 3-17, 2020 at the LPPT Unit IV, Gajah Mada University. This was a true experimental with post-test only control group study on 35 male wistar rats as the experimental animals. The rats were divided into 5 groups: P1, P2, and traumatic brain injury groups that received Centella asiatica (L.) treatement at 150, 300, and $600 \mathrm{mg} / \mathrm{kgBW} / \mathrm{d}$ doses, respectively. Blood samples were collected after the experimental animals were terminated to assess serum TNF- $\alpha$ levels. Mean TNF- $\alpha$ levels were $60,980 \pm 4,057,76,931 \pm 0,698, P 3=75,889 \pm 0,948, P 4=75,868 \pm 1,163$, and 74,508 $\pm 1,126$ for P1, P2, P3, P4, and P5, respectively. The Kruskal Wallis test results showed a statistically different between groups ( $\mathrm{p}=0.005)$. This study shows that Centella asiatica (L.) can decrease serum TNF- $\alpha$ level in rat model of traumatic brain injury.
\end{abstract}

Keywords: Centella asiatica (L.) extract, TNF- $\alpha$, traumatic brain injury

\section{Efek Anti-Inflamasi Ekstrak Centella asiatica (L.) pada Kadar TNF- $\alpha$ Serum Tikus Model Cedera Otak Traumatik}

\begin{abstract}
Abstrak
Centella asiatica (L.) mengandung berbagai kandungan aktif yang memiliki efek antioksidan, antiinflamasi dan neuroprotektan. Centella asiatica (L.) dapat menurunkan reaksi inflamasi melalui hambatan terhadap aktivitas TNF- $\alpha$. Centella asiatica (L.) berpotensi sebagai terapi alternatif dalam menurunkan inflamasi pada traumatic brain injury (TBI) via modulasi ekspresi TNF- $\alpha$. Penelitian ini bertujuan menguji pengaruh pemberian Centella asiatica (L.) pada kadar TNF- $\alpha$ serum, tikus model TBI. Penelitian ini dilaksakanan pada 3-17 Juli 2020 di LPPT Unit IV Universitas Gajah Mada. Penelitian ini menggunakan desain penelitian true experimental design dengan post test only controlled group design. Penelitian ini menggunakan hewan coba tikus jantan strain wistar sebanyak 35 ekor. Sampel dibagi menjadi 5 kelompok, yaitu: P1, P2, dan kelompok model trauma dan diberi perlakuan Centella asiatica (L.) masing-masing dosis 150, 300, dan $600 \mathrm{mg} / \mathrm{kgBB} / \mathrm{h}$. Pengambilan sampel darah dilakukan setelah terminasi hewan coba untuk menilai kadari TNF- $\alpha$ serum. Rerata TNF- $\alpha$ pada P1 $=60,980 \pm 4,057$; $\mathrm{P} 2=76,931 \pm 0,698 ; \quad \mathrm{P} 3=75,889 \pm 0,948 ; \quad \mathrm{P} 4=75,868 \pm 1,163$; dan $\mathrm{P} 5=74,508 \pm 1,126$. Hasil Uji Kruskal Wallis menunjukan terdapat perbedaan bermakna signifikan secara statistik $(\mathrm{p}=0,005)$. Penelitian ini membuktikan bahwa ekstrak Centella asiatica (L.) berpengaruh dalam penurunan kadar TNF- $\alpha$ serum tikus model TBI.
\end{abstract}

Kata kunci: Ekstrak Centella asiatica (L.), TNF- $\alpha$, traumatic brain injury

Corresponding Author: Nafiisah, Histology Department, Faculty of Medicine Jenderal Soedirman University, Jalan dr. Gumbreg No.1 Mersi, Purwokerto Timur, Purwokerto 53112,Email: dr.nafiisah@unsoed.ac.id 


\section{Introduction}

Traumatic brain injury (TBI) is a pathological process in brain tissue that is not caused by degenerative or congenital processes but due to external mechanical forces (trauma). ${ }^{1}$ In Indonesia, the national prevalence of injury was $11.9 \%$ in 2018, showing an increasing trend from the previous prevalence of $8.2 \%$ in $2013 .^{2}$ In the United States, head injuries account for more than 1.7 million of all injuries and are the third cause of injury-related deaths. ${ }^{3}$

Two stages are involved in traumatic brain injury: primary injury and secondary injury. ${ }^{4}$ The primary brain injury occurs immediately while the secondary brain injury occurs some time after. $^{5}$ One of the manifestations of TBI is the presence of an inflammatory response with increased expression of proinflammatory cytokine, one of which is the tumor necrosis factor- $\alpha$ (TNF- $\alpha){ }^{6}$

TNF- $\alpha$ plays a role in the apoptotic process. Apoptosis can occur in two ways: caspasedependent and caspase-independent. The caspase-dependent pathway can occur extrinsically, initiated by the stimulation of TNF death receptors, whereas the intrinsic pathway is initiated by the release of signaling factors from mitochondria in the cells. Meanwhile, apoptosis of the caspase-independent pathway is triggered without going through the caspase activity. ${ }^{7}$

The use of medicinal plants as a therapy for brain injury is still rare. One of the medicinal plants used is Centella asiatica (L.) or gotu kola. Several studies have stated that the active compounds in Centella asiatica (L.) play a neuroprotective role contributed by their antioxidant and anti-inflammatory properties. These active compounds include asiatic acid, asiaticoside, madecassic acid, flavonoids, and madecassoside. The effect of neurotprotective therapy is explained through research that demonstrated the provision of ethanol extract of Centella asiatica (L.) can improve the neurological function in rats induced by traumatic brain injury with the principle of weight drop injury. ${ }^{8}$

This suggests that Centella asiatica (L.) has a potential as an alternative therapy to reduce TNF- $\alpha$ levels in traumatic brain injury. Thus, Centella asiatica (L.) provision is expected to prevent secondary injury complications that may occur. The purpose of this study was to assess the effect of Centella asiatica (L.) extract on traumatic brain injury in rat model.

\section{Methods}

The study was conducted in July 3-17, 2020 at LPPT Unit IV, Gajah Mada University. This study used the Post Test Only Controlled Group true experimental design on the wistar strain rat (Rattus norvegicus). The inclusion criteria used were white wistar rats, male, 2-3 months old, between 150-200 grams of weight, healthy, and active. Rats who were sick and dead during acclimatization and study were excluded.

Five groups were identified to assign these rats: group 1 (P1) that consisted of rats with no brain trauma and without Centella asiatica (L.) extract provision; group 2 (P2) that consisted of rat models of traumatic brain injury and CMC; group 3 ( P3) that consisted of rat models of traumatic brain injury with a provision of $150 \mathrm{mg} /$ $\mathrm{kg}$ /day Centella asiatica (L.) extract; group 4 (P4) that included rat models of traumatic brain injury with a provision of $300 \mathrm{mg} / \mathrm{kgBW} /$ day Centella asiatica (L.) extract, and group 5 (P5) that included rat models of traumatic brain injury and with a provision of $600 \mathrm{mg} / \mathrm{kgBW} /$ day Centella asiatica (L.) extract. Seven rats were assigned in each group.

All protocols related to these experimental animals have been approved by the Research Ethics Commission of the Faculty of Medicine, Jenderal Soedirman niversity (039/KEPK/ IV/2020).

As many as 35 rats were purchased and maintained at the Integrated Research and Testing Laboratory (LPPT) unit IV Gajah Mada University, Yogyakarta. These rats were acclimatized for adaptation purpose for 7 days under the maintenance standard of experimental animals.

Rats were anesthetized and had their head shaved and cleaned with $70 \%$ alcohol bfore the scalp was opened. They were then placed on a flatbed with their four legs tied to fix them on a hard base. An iron cylinder weighing 45 grams ( $4 \mathrm{~mm}$ diameter) was dropped at an angle of 90 from $25 \mathrm{~cm}$ height. This was done once.

The Centella asiatica (L.) plant was washed and then dried under the sun first and then heated. The simplicia was made into powder using a grinder. The fine powder was macerated using 96\% ethanol solvent, then left for 24 hours. The macerated fine powder was further remacerated using 96\% ethanol and then let to stand for another 24 hours before being filtered using a bunchner. The filtrate obtained was concentrated using a rotary evaporator at a temperature of $40^{\circ} \mathrm{C}$ until a thick extract was 
obtained. The extract was dried with a water bath at $60^{\circ}-70^{\circ}$ and then dissolved with $0.5 \%$ CMC as the surfactant. Centella asiatica (L.) therapy was given orally using a nasogastric tube every day for 7 days at a dose of 150, 300, and $600 \mathrm{mg} /$ $\mathrm{kgBW} /$ day for group 3, 4, and 5, respectively.

Blood samples were collected after termination of the experimental animals by means of decapitation. Blood samples were collected from the orbital veins and centrifuged at 4,000 rpm for 15 minutes to obtain rat serum. Examination of serum TNF- $\alpha$ levels were performed using Rat Tumor Necrosis Factor with Elisa Kit 9 (BT-Lab) with a wavelength of $450 \mathrm{~nm}$.

Data in the form of serum TNF- $\alpha$ levels were analyzed descriptively by calculating the mean and standard deviations and presented in tables and charts. Data normality test was conducted using the Saphiro-Wilk test. Hypotesis for the serum TNF- $\alpha$ level were tested using Kruskal Wallis non-parametric test, followed by the Post Hoc (Mann Whitney) test to determine the differences between groups, which were considered statistically significant if $\mathrm{p}<0.05$.

\section{Results}

Table 1 presents the mean results of serum TNF- $\alpha$ level measurements of each treatment group. A decrease in serum TNF- $\alpha$ level was seen with increasing dose of Centella asiatica (L.) extract, which was statistically significant based on the results of the Kruskal Wallis test $(p=0.005)$ can be seen. This proves that Centella asiatica (L.) extract can reduce proinflammatory cytokine TNF- $\alpha$ level, which will trigger apoptosis.

The results of the Kruskal Wallis test were then further analyzed using the Post Hoc Man Whitney test where the results were shown nd the results showed that there were significant differences between P1-P2 ( $p=0.002), P 1-P 3$

Table Kruskal Wallis Test Results Serum TNF- $\alpha$ levels (ng/L)

\begin{tabular}{cccc}
\hline Group & Mean \pm SI & p value & Exp. \\
\hline P1 & $60.980 \pm 4.057$ & 0.005 & Significant \\
P2 & $76.931 \pm 0.698$ & & \\
P3 & $75.889 \pm 0.948$ & & \\
P4 & $75.868 \pm 1.163$ & & \\
P5 & $74.508 \pm 1.126$ & & \\
\hline
\end{tabular}

$(\mathrm{p}=0.004), P 1-\mathrm{P} 4(\mathrm{p}=0.006)$, and P1-P5 ( $=$ $0.025)$.

\section{Discussion}

The administration of Centella asiatica (L.) extract in various doses in this study has been demonstrated to successfully reduce the serum TNF- $\alpha$ level in rats model of traumatic brain injury after 7 days of administration. The results of this study are in line with findings of Rochmah et al. ${ }^{16}$ that the group receiving Centella asiatica (L.) extract of $600 \mathrm{mg} / \mathrm{kg}$ has the lowest concentration of hippocampal TNF- $\alpha$ when compared to other groups after all groups receive stress.

Centella asiatica (L.) is a medicinal plant that has neuroprotective effects contributed by its strong antioxidant and anti-inflammatory effects. Centella asiatica (L.) has the ability to reduce inflammatory reactions through TNF- $\alpha$ activity inhibition. The administration of Centella asiatica (L.) extract can reduce the TNF- $\alpha$ level, along with the increase in extract concentration in rat nerve cell cultures of Wistar strain rats (Rattus novergicus) induced by LPS (Lipopolysacarida). ${ }^{9}$ Centella asiatica (L.) extract can also reduce the expression of proinflammatory cytokines, one of which is TNF- $\alpha$, in arthritis rats. ${ }^{10}$

Centella asiatica (L.) has several ingredients with antioxidant and anti-inflammatory nature that can provide neuroprotective effects including, among others, asiatic acid, asiaticoside, madecassic acid, and flavonoids. Asiatic acid triggers an anti-inflammatory effect by reducing pro-inflammatory cytokines in LPSstimulated human corneal epithelial cells, while asiaticoside had an anti-inflammatory effect in rat given LPS through Heme Oxygenase-1 regulation. ${ }^{11,12}$ The latter gains its effect through the pro-inflammatory mediator inhibition, such as TNF- $\alpha$ and IL- 6 inhibition; COX-2 expression, PGE production , and MPO activity. ${ }^{12}$

Furthermore, the madecoside content in Centella asiatica (L.) has significant antiinflammatory properties comparable to mefenamic acid that support its use as a traditional plant for treatinginflammation or rheumatism. Histopathological examination shows that madecosides are able to reduce inflammatory cell infiltration and synovial hyperplasia, as well as providing protection against joint damage. ${ }^{13}$

Flavonoids, which are the main antioxidants most commonly found in the leaves of the 
Centella asiatica (L.) plant is shown recently to inhibit regulatory enzymes or transcription factors that are important for controlling mediators of inflammatory process. ${ }^{14}$ Flavonoids are also known as powerful antioxidants that have the potential to dilute tissue damage or fibrosis. Therefore, various in vitro studies in various experimental animal models have shown that flavonoids have the potential to inhibit the emergence and development of inflammatory process. ${ }^{15}$ In addition to Centella asiatica (L.), there are still various medicinal plants that contain flavonoids, including Ketepeng China plant (Cassia alata (L.)), Iler plant (Coleus scutellariodes (L.) Benth), and nut-grass (Cyperus rotundus (L.)). ${ }^{17}$

This study shows that Centella asiatica (L.) can decrease the serum TNF- $\alpha$ level in the rat model of traumatic brain injury.

\section{References}

1. Freire MA. Pathophysiology of neurodegeneration following traumatic brain injury. West Indian Med J. 2012;61(7):751-5.

2. Kementerian Kesehatan RI Badan Penelitian dan Pengembangan. Hasil utama Riset Kesehatan Dasar. Jakarta: Badan penelitian dan Pengembangan Kesehatan Kementerian Kesehatan Republik Indonesia; 2018;

3. Faul M, Xu L, Wald MM, Coronado VG. Traumatic Brain Injury in the United States: Emergency Department Visits, Hospitalizations and Deaths 2002-2006. Atlanta: Centers for Disease Control and Prevention, National Center for Injury Prevention and Control; 2010. p. 1-74.

4. Badjatia N, Carney N, Crocco TJ, Fallat ME, Hennes HMA, Jagoda AS, et al. Guidelines for prehospital management of traumatic brain injury 2nd edition. Prehospital Emergency Care. 2008;12(1):1-522.

5. Prasetyo $\mathrm{BH}$, Handono $\mathrm{K}$, Dalhar $\mathrm{M}$. Pengaruh pemberian ekstrak propolis terhadap ekspresi TLR4 dan apoptosis pada jaringan otak tikus model traumatic brain injury (TBI). Jurnal Kedokteran Brawijaya. 2017;29(4):287-92.

6. Andrzejowski J, Fraser J. Cottrell and Young's Neuroanaesthesia. British Journal of Anaesthesia. 2010;105(5):704-6.

7. Sari LM. Apoptosis: mekanisme molekuler kematian sel. Cakradonya Dental Journal. 2018;10(2):65-70.

8. Jazmi AF, Alfiantya PF, Nurarifah SAH,
Purmitasari EA, Vitania LA, Riawan W. Spade leaf extract phytosome modulates krox-20, neuregulin-1, phospholipids, and cognitive function of traumatic brain injury model in rats. Indonesian Journal of Cancer Chemoprevention. 2017;6(3):105-10.

9. Khotimah H, Riawan W, Kalsum U. Efek neuroprotektif ekstrak pegagan (centella asiatica) terhadap BDNF (Brain-Derived Neurotropic Factor), TNFaR, NFkB dan apoptosis pada kultur sel syaraf yang diinduksi LPS. Laporan Hibah Penelitian Strategis Nasional. Direktorat Jenderal Pendidikan Tinggi, Departemen Pendidikan Nasional; 2009; p. 1-9.

10. Sharma S, Thakur SC. Centella asiatica extract protects against both inflammation and oxidative stress in collagen-induced arthritis rat model. J Nat Sc Biol Med. 2011;(2 Suppl S1):S117.

11. Chen H, Hua XM, Ze BC, Wang B, Wei L. The anti-inflammatory effects of asiatic acid in lipopolysaccharide-stimulated human corneal epithelial cells. Int J Ophthalmol. 2017;10(2):179-85.

12. Wan J, Gong X, Jiang R, Zhang Z, Zhang L. Antipyretic and anti-inflammatory effects of asiaticoside in lipopolysaccharide-treated rat through up-regulation of heme oxygenase-1. Phytother Res. 2013;27(8):1136-42.

13. George M, Joseph L, Ramaswamy. Antiallergic, anti-pruritic, and anti-inflammatory activities of Centella asiatica extracts.Afr J Tradit Complement Altern Med. 2009;6(4): 554-9.

14. Chong NJ, Aziz Z. A systematic review on the chemical constituents of Centella asiatica. Research J Pharmaceutical Bioogical Chemical Science. 2011;2(3):445-59.

15. Maleki SJ, Crespo JF, Cabanillas B. Antiinflammatory effects of flavonoids. Food Chemistry. 2019;299(2019):1-11.

16. Rochmah MA, Harini IM, Septyaningtrias DE, Sari DCR, Susilowati R. Centella asiatica prevents increase of hippocampal tumor necrosis factor- $\alpha$ independently of its effect on brain-derived neurotrophic factor in rat model of chronic stress. Biomed Research Int. 2019;1-7.

17. Lumbessy M, Abidjulu J, Paendong JJ. Uji total flavonoid pada beberapa tanaman obat tradisonal di Desa Waitina Kecamatan Mangoli Timur Kabupaten Kepulauan Sula Provinsi Maluku Utara. Jurnal MIPA. 2013; 2(1):50-5. 